\title{
Assessment of Genetic Variability for Yield and Yield Components in Rice (Oryza sativa L.) Germplasms
}

\author{
Akhand Pratap, Prashant Bisen, Bapsila Loitongbam, Sandhya and P. K. Singh*
}

Dept. of Genetics and Plant Breeding, Institute of Agricultural Sciences, Banaras Hindu University, Varanasi, U.P. (221 005), India

\section{Corresponding Author}

P. K. Singh

e-mail: pksbhu@gmail.com

\author{
Article History \\ Article ID: 3 C0818 \\ Received in $31^{\text {st }}$ October, 2017 \\ Received in revised form $24^{\text {th }}$ December, 2017 \\ Accepted in final form $28^{\text {th }}$ January, 2018
}

\begin{abstract}
Thirty eight rice germplasms were evaluated to assess their genetic variability, heritability, genetic advance, correlation and direct- indirect effect for grain yield and yield contributing traits. The analysis of variance revealed significant differences for all the characters under study, indicating the presence of high genetic variability among the genotypes. The genotype CRR599-4-1 was found to be the best for grain yield and effective tiller plant ${ }^{-1}$, panicle length, test weight and spikelet fertility per cent on the basis of per se performance. The high estimates of GCV and PCV were observed for traits like grain yield per plant, filled grains panicle ${ }^{-1}$, effective tillers plant ${ }^{-1}$ indicating their importance in selection for improving the rice yield. High heritability coupled with high expected genetic advance as percent of mean was observed for the traits field grain panicle ${ }^{-1}$, spikelet fertility percentage and days to maturity. Grain yield plant ${ }^{-1}$ had strong positive association with spikelet fertility percentage, filled grain panicle ${ }^{-1}$, effective tiller plant ${ }^{-1}$, plant height and test weight and significant positive correlation with plant height, effective tillers plant ${ }^{-1}$, test weight, filled grains panicle ${ }^{-1}$ and spikelet fertility. Path coefficient analysis revealed that days to $50 \%$ flowering, plant height, number of effective tiller, panicle length, test weight and filled grain panicle ${ }^{-1}$ exhibit positive direct effect on grain yield plant ${ }^{-1}$.
\end{abstract}

Keywords: Rice, GCV, PCV, heritability, genetic advance

\section{Introduction}

Grain yield is a complex trait and is the result of interaction of many variables (Singh et al., 2015a). Though a wide range of genetic variability has been reported for yield traits in the past, but still there exists untapped genetic variability in germplasms which is of paramount importance in selecting the potential parents so as to get maximum heterosis and superior recombinants (Rashmi et al., 2017). Genetic improvement for quantitative traits depends on the nature and amount of variability present in the genetic stock and the extent to which the desirable traits are heritable (Namrata et al., 2016). The knowledge about genetic variability of yield contributing characters, inter relationship among them and their relation with yield are necessary for an effective breeding programme (Nayak et al., 2016). Knowledge concerning heritability helps plant breeders to predict the nature of the succeeding generation, to make an appropriate selection and to assess the magnitude of genetic improvement through selection (Tuhina Khatun et al., 2015). In addition, high genetic advance coupled with high heritability offers the most effective condition for selection for a specific character (Larik and Rajput, 2000). The association of different characters was essential to determine their contribution towards yield. Correlation studies provide an opportunity to study the magnitude and direction of association among different traits with grain yield and their direct and indirect effect on grain yield (Solanki et al., 2017). In this context, an attempt was made to assess genetic variability for yield characteristics and unravel the correlation of different grain yield traits among a set of thirty eight rice germplasms.

\section{Materials and Methods}

\subsection{Experimental material, location, and experimental design}

Thirty eight rice germplasms viz., C-1, C-2, C-3, C-6, C-7, SANGSANGBA, MOIRANG PHOU, MOIRANG PHOU KHONG NEMBT, KUMBI PHOU, LANG PHOU, LOKTAK PAT PHOU, TUMAT AMUBI, BARASALI, IR78933-B24-B-B-4, HURLC-40, CR3488-1-2-1-2, CRR599-51, OR2172-7-1, CRR599-4-1, R1570418-1-149-1, NDR-1159, UPRI 2012-15, RPBIO4918-70-11, IR 83142-60, HURLC 22, IR82635-B-B47-1, BVS 1, IC 256649, CR 3635-1-1, JALNIDHA, LAL KHADHAN, IC 426013, HURL-54, DHAULAKISH, CSR-36, IC 337598, TETEP (Check), received from DBT Networking Project, Institute of Agricultural Sciences, Banaras Hindu University, Varanasi were evaluated at Agricultural Research Farm, BHU, Varanasi, which is located 
in North-eastern zone of Uttar Pradesh at $25.18^{\circ} \mathrm{N}$ latitude and $83.03^{\circ} \mathrm{E}$ longitude and at altitude of $75.5 \mathrm{~m}$ from sea level. This eastern Indo-Gangetic Plains is very fertile due to annual low level floods in the Ganges. The experiment was laid out in randomized block design (RBD) with three replications. The nursery was sown on $14^{\text {th }}$ June, 2016 on uniform raised beds applied with a fertilizer dose of $1.0 \mathrm{~kg} \mathrm{~N}, 1.0 \mathrm{~kg} \mathrm{P}_{2} \mathrm{O}_{5}$ and 0.5 $\mathrm{kg} \mathrm{K}_{2} \mathrm{O}$ per $50 \mathrm{~m}^{2}$ area. Twenty five days old seedlings were transplanted in main research plot with one seedling hill-1. Each plot consisted of five rows of $1.5 \mathrm{~m}$ length with spacing $(15 \times 20) \mathrm{cm}^{2}$. The recommended agronomic practices were followed to raise a good and healthy crop.

\subsection{Data collection}

Observations were recorded on ten randomly selected plants of each germplasm in each replication for eleven quantitative traits viz., days to $50 \%$ flowering, days to maturity, plant height $(\mathrm{cm})$, panicle length $(\mathrm{cm})$, number of spikelet, effective tillers per plant, filled grains panicle ${ }^{-1}$, total grains panicle ${ }^{-1}$, spikelet fertility per cent, Test weight (gm) and Total yield per plant (gm).

\subsection{Statistical analyses}

Univariate analysis of the individual character (ANOVA) including the estimation of mean, range and coefficient of variation (CV\%) was conducted and interrelationships among traits values were estimated using SAS software version 9.1 (SAS Institute, 1998). Differences were called statistically significant at $p<0.05$. Phenotypic coefficient of variation (PCV) and genotypic coefficient of variation (GCV) were calculated by the formula given by Burton and Devane (1953). Heritability in broad sense $\left(h^{2}\right)$ and genetic advance as percent of mean were estimated by the formula as suggested by Allard (1960). The correlation coefficient among pairs of characters was calculated according to the formula suggested by Searle (1961). To test the significance of correlation coefficients, the estimated values were compared with the table value (statistical table by Fisher and Yates, 1963) at n-2 degrees of freedom (where $n$ denotes the number of genotypes tested) at $5 \%$ and $1 \%$ level of significance. Path coefficient analysis was done to partition the total correlation into direct and indirect effects due to the dependent variable. Wright (1934) suggested this analysis and it was further elaborated by Dewey and Lu (1959).

\section{Results and Discussion}

\subsection{Analysis of variance}

The studies of variance among thirty-eight genotypes for eleven quantitative traits revealed that the genotypes differed significantly for all the traits (Table 1), which suggested that the materials selected for the studies might be of diverse origin. Several workers have reported the presence of variability and amongst the genotypes of rice for different quantitative traits. These findings are in accordance with the findings of Shobha et al. (2001); Yadav et al. (2002); Satyanarayana et al. (2005); Mustafa and Elsheikh (2007); Khare et al. (2015), Islam et al. (2016); Shah et al. (2017); Rashmi et al. (2017); Tripathi et al. (2017).

\begin{tabular}{lcccccccccccc}
\hline \multicolumn{10}{l}{ Table 1: Analysis of variance (ANOVA) for eleven quantitative traits in thirty eight rice genotypes } \\
\hline Source of & D.F & \multicolumn{10}{c}{ Mean Sum of Squares } \\
\cline { 2 - 14 } variation & & DF & DM & PH & ETPP & PL & TGPP & NFS & TW & FGPP & SF (\%) & GYPP \\
\hline Replication & 2 & 5.64 & 2.92 & 43.09 & 0.54 & 0.45 & 45.77 & 0.00 & 0.32 & 0.10 & 2.89 & 2.08 \\
Treatment & 37 & $489.09^{*}$ & $541.40^{*}$ & $1544.17^{*}$ & $16.49^{*}$ & $8.23^{*}$ & $2552.02^{*}$ & $7.92^{*}$ & $35.34^{*}$ & $2952.10^{*}$ & $781.03^{*}$ & $127.09^{*}$ \\
Error & 74 & 5.04 & 3.50 & 50.64 & 0.47 & 1.24 & 35.83 & 0.21 & 0.24 & 4.08 & 5.94 & 1.24 \\
\hline
\end{tabular}

*Significant at $p<0.001$

\subsection{Per se performance}

Genotype C-2 was found earliest in flowering (74 days) and maturity (102 days) suggesting that this genotype can be used as a donor in hybridization programme for evolving early maturity or short duration rice variety (Table 2). Genotype IC256649 and IR 82635-B- B47-1 was recorded as the shortest and tallest, respectively. The highest mean performance for effective tillers per plant was observed in genotype IR8314-60 (15 tillers) followed by CRR-599-4-1 (14 tillers) and R-1570418-1-149-1 (13 tillers). Genotype IC 337598 exhibited highest mean performance for panicle length followed by genotype JALNIDHA and HURLC-54. Genotype CRR 599-4-1 (36.89 g) recorded highest mean performance for grain yield plant ${ }^{-1}$ followed by IR 83142-60 (29.24 g) and BARASALI (27.47 g) indicating that these genotypes can be used in hybridization programme in order to achieve desirable hybrids for yield.

\subsection{Variation and genetic parameters among accessions}

The amount of genetic variability present, decides the effectiveness of selection. The extent of variability as measured by phenotypic coefficient of variation (PCV) and genotypic coefficient of variation (GCV) provides information regarding the relative amount of variation for various traits. Here, the estimates of PCV were higher than their corresponding GCV for all the traits studied, but the difference is very less indicating the presence of environmental influence to some degree in the phenotypic expression of the traits (Table 3). Similar results were reported by Souroush et al. (2004), Satyanarayana et al. (2005); Patra et al. (2006); Subudhi et al. (2011); Singh et al. (2013), Singh et al. (2014); Khare et al. 
Table 2: Variability parameters for eleven quantitative characters in thirty eight rice germplasms

\begin{tabular}{|c|c|c|c|c|c|c|c|c|c|c|c|}
\hline Trait & DF & DM & $\mathrm{PH}(\mathrm{cm})$ & ETPP & $\mathrm{PL}(\mathrm{cm})$ & TGPP & NFS & TW & FGPP & SF (\%) & GYPP (g) \\
\hline Range & 74.00 & 102.00 & 80.73 & 5.46 & 19.20 & 103.53 & 8.26 & 13.99 & 59.60 & 28.83 & 4.78 \\
\hline Max. & 125.33 & 154.33 & 180.40 & 15.26 & 28.13 & 224.06 & 16.66 & 31.19 & 189.66 & 91.74 & 36.89 \\
\hline Grand Mean & 90.52 & 120.24 & 131.83 & 9.88 & 25.02 & 157.99 & 11.32 & 23.06 & 110.93 & 70.88 & 17.17 \\
\hline SE $( \pm)$ & 1.29 & 1.07 & 4.10 & 0.39 & 0.64 & 3.45 & 0.26 & 0.28 & 1.16 & 1.40 & 0.64 \\
\hline PCV (\%) & 14.25 & 11.24 & 17.77 & 24.40 & 7.55 & 18.72 & 14.73 & 14.99 & 28.32 & 22.94 & 38.27 \\
\hline GCV (\%) & 14.03 & 11.14 & 16.93 & 23.39 & 6.10 & 18.33 & 14.16 & 14.83 & 28.26 & 22.68 & 37.71 \\
\hline h2 \% (broad sense) & 0.97 & 0.98 & 0.91 & 0.92 & 0.65 & 0.96 & 0.92 & 0.98 & 1.00 & 0.98 & 0.97 \\
\hline GA as $\%$ of mean (5\%) & 28.47 & 22.72 & 33.22 & 46.21 & 10.15 & 36.98 & 28.02 & 30.24 & 58.09 & 46.19 & 76.57 \\
\hline GA as $\%$ of mean (1\%) & 36.48 & 29.12 & 42.57 & 59.22 & 13.01 & 47.39 & 35.91 & 38.76 & 74.45 & 59.19 & 98.12 \\
\hline
\end{tabular}

DF: Days to 50\% flowering; DM: Days to Maturity; PH: Plant height; ETPP: Number of effective tillers plant ${ }^{-1}$; PL: Panicle length; TGPP: Total grains panicle ${ }^{-1}$; NFS: Number of fertile spikelet; TW: Test weight; FGPP: filled grains panicle ${ }^{-1}$; SF: Spikelet fertility percent; GYPP: Grain yield plant ${ }^{-1}$

Table 3: Estimates of Phenotypic Correlation between yield and its related trait in thirty eight genotypes of rice

\begin{tabular}{|c|c|c|c|c|c|c|c|c|c|c|}
\hline Character & DF & DM & $\mathrm{PH}$ & ETPP & $\mathrm{PL}$ & TGPP & NFS & TW & FGPP & SF \\
\hline DF & 1.00 & $0.970^{* * *}$ & $0.383^{* * *}$ & 0.145 & 0.015 & $0.193^{*}$ & $0.355^{* * *}$ & $-0.206^{*}$ & -0.182 & $-0.349^{* * *}$ \\
\hline DM & & 1.00 & $0.391^{* * *}$ & 0.114 & 0.027 & $0.237^{*}$ & $0.403^{* * *}$ & -0.152 & -0.119 & $-0.324^{* * *}$ \\
\hline $\mathrm{PH}$ & & & 1.00 & 0.124 & $0.298^{* *}$ & 0.110 & $0.199^{*}$ & $0.327^{* * *}$ & 0.178 & 0.154 \\
\hline ETPP & & & & 1.00 & 0.024 & $-0.311^{* * *}$ & $-0.365^{* * *}$ & $-0.426^{* * *}$ & $-0.250^{* *}$ & 0.018 \\
\hline$P L$ & & & & & 1.00 & 0.038 & 0.004 & $0.289^{* *}$ & -0.022 & -0.058 \\
\hline TGPP & & & & & & 1.00 & $0.66^{* * *}$ & $-0.192^{*}$ & $0.467^{* * *}$ & $-0.228^{*}$ \\
\hline NFS & & & & & & & 1.00 & 0.142 & $0.464^{* * *}$ & 0.00 \\
\hline TW & & & & & & & & 1.00 & $0.246^{* *}$ & $0.380^{* * *}$ \\
\hline FGPP & & & & & & & & & 1.00 & $0.730^{* * *}$ \\
\hline SF & & & & & & & & & & 1.00 \\
\hline GYPP & $-0.1945^{*}$ & -0.1639 & $0.3421^{* * *}$ & $0.3923^{* * *}$ & 0.0881 & -0.0673 & -0.0606 & $0.2432^{* *}$ & $0.5397^{* * *}$ & $0.663^{* * *}$ \\
\hline
\end{tabular}

"Significant at $p<0.05 ;{ }^{* *}$ Significant at $p<0.01 ;{ }^{* * *}$ Significant at $p<0.005 ;{ }^{* * *}$ Significant at $p<0.001$

(2015), Nayak et al. (2016) and Rashmi et al. (2017).

The highest PCV and GCV were recorded for grain yield plant ${ }^{-1}$ $(38.27,37.71)$ followed by filled grains panicle ${ }^{-1}(28.32,28.26)$ and effective tillers plant ${ }^{-1}(24.40,23.39)$, respectively (Table 2). Result suggested that these traits like grain yield plant ${ }^{-1}$ and filled grains panicle ${ }^{-1}$ were under the major influence of genetic control and less variable due to environmental factor. Therefore, such traits could be relied upon and selection can be practiced for further improvement. The present findings were in consonance with earlier reports made by Singh et al. (2013); Chouhan et al. (2014); Sawarkar and Senapati (2014); Singh et al. (2015); Tuhina Khatun et al. (2015); Anis et al. (2016).

\subsection{Heritability and Genetic Advance estimates}

Heritability and genetic advance are important selection parameters. Highest heritability was recorded for filled grain panicle ${ }^{-1}(100 \%)$ followed by spikelet fertility, days to maturity and test weight (98\%) whereas lowest heritability was recorded for panicle length (Table 2). Similar reports were also made by Satyanarayana et al. (2005) and Rashmi et al. (2017). This indicated that selection of these traits would be more effective as compared to others. The breeder should be cautious in making selection based on heritability as it indicates both additive and non-additive gene action. Thus, heritability values coupled with genetic advance would be more reliable and useful in formulating selection procedure as it indicates that most likely the heritability is due to additive gene effects. Genetic advance as percent of mean (5\%) was recorded highest for grain yield panicle ${ }^{-1}(76.57)$ followed by filled grains panicle ${ }^{-1}(58.09)$ and effective tillers per plant (46.21). While lowest for panicle length (10.15) followed by days to maturity (22.72) and number of fertile spikelet (28.02). High heritability coupled with high genetic advance 
as percent was recorded for filled grain panicle ${ }^{-1}$, spikelet fertility percentage and test weight indicating effectiveness of selection for the improvement of these traits while high heritability coupled with low genetic advance as percent of mean were observed for grain yield plant ${ }^{-1}$, effective tiller plant $^{-1}$ which is indicating of non-additive gene action (Table 2). The high heritability is being exhibited due to favorable influence of environment rather than genotype and selection for such traits may not be rewarding. These results are in conformity with the findings of Krishna et al. (2010); Singh et al. (2012); Sawarkar and Senapati (2014); Tripathi et al. (2017).

\subsection{Correlation coefficient analysis}

Correlation coefficient analysis measures the mutual relationship between various plant characters and component characters on which selection can be based for genetic improvement in yield. A positive correlation between desirable characters is favorable to the plant breeder because it helps in simultaneous improvement of both the characters. The results on correlation analysis showed that spikelet fertility percentage has positive and highly significant association with filled grain per panicle, effective tiller per plant, plant height and test weight. Similar results were also reported by Joshi et al. (2015); Haradari and Hittalmani (2017). Whereas, characters like days to $50 \%$ flowering showed negative and significant correlation and days to maturity, total grain per panicle and number of fertile spikelet have showed negative and non-significant. This was in accordance with the findings of Pankaj et al. (2010). Grain yield plant ${ }^{-1}$ was positively and significantly correlated withplant height, effective tillers plant $^{-1}$, test weight, filled grains panicle ${ }^{-1}$ and spikelet fertility (Table 3). Similar results were also reported by Akhter et al. (2004); Singh et al. (2013); Sawarkar and Senapati (2014).

\subsection{Path coefficient analysis}

Traits like days to $50 \%$ flowering, plant height, number of effective tiller, panicle length, test weight and filled grain per panicle exhibit positive direct effect while days to maturity, total grain panicle ${ }^{-1}$, fertile spikelet and spikelet fertility percentage had negative direct effect on grain yield plant ${ }^{-1}$ (Table 4). Ganesan (2001); Panwar et al. (2007); Haradari and Hittalmani (2017) have also reported similar type of finding in rice. The strong positive association of days to $50 \%$ flowering with grain yield plant ${ }^{-1}$ was mainly through its direct effect. However, it was also due to the indirect effect through plant height, effective tiller, spikelet fertility percentage, filled grains per panicle, total grains panicle ${ }^{-1}$, panicle length and test weight. The direct effect of days to $50 \%$ flowering on grain yield plant $^{-1}$ was positive and negligible. Many researchers reported similar findings like Panwar et al. (2007). Whereas, the indirect effect of days to $50 \%$ flowering via days to maturity was found to be negative. Therefore, selection based on these traits will be effective in improving grain yield and other related traits. The magnitude of residual effect (0.49) indicated that there may be few more characters which could have been include for estimation of direct and indirect contributors towards their relationship with grain yield plant ${ }^{-1}$.

Table 4: Estimates of Phenotypic path matrix of eleven quantitative traits on grain yield plant ${ }^{-1}$ in thirty eight genotypes of rice

\begin{tabular}{lcccccccccc}
\hline Character & DF & DM & PH & ETPP & PL & TGPP & NFS & TW & FGPP & SF \\
\hline DF & 0.0187 & 0.0181 & 0.0071 & 0.0027 & 0.0003 & 0.0036 & 0.0066 & -0.0038 & -0.0034 & -0.006 \\
DM & -0.0947 & -0.0976 & -0.0382 & -0.0112 & -0.0026 & -0.0232 & -0.0394 & 0.0148 & 0.0116 & 0.032 \\
PH & 0.0419 & 0.0429 & 0.1095 & 0.0136 & 0.0326 & 0.0121 & 0.0218 & 0.0358 & 0.0195 & 0.017 \\
ETPP & 0.0944 & 0.0746 & 0.0810 & 0.6498 & 0.0158 & -0.2022 & -0.2376 & -0.2772 & -0.162 & 0.012 \\
PL & -0.0007 & -0.0013 & -0.0142 & -0.0012 & -0.0477 & -0.0019 & -0.0002 & -0.0138 & 0.001 & 0.003 \\
TGPP & -0.0032 & -0.0039 & -0.0018 & 0.0052 & -0.0007 & -0.0166 & -0.0111 & 0.0032 & -0.008 & 0.004 \\
NFS & -0.0675 & -0.0767 & -0.0378 & 0.0696 & -0.0008 & -0.1269 & -0.1903 & -0.0271 & -0.088 & 0.000 \\
TW & -0.0734 & -0.0542 & 0.1167 & -0.1523 & 0.1035 & -0.0685 & 0.0508 & 0.3570 & 0.088 & 0.136 \\
FGPP & -0.1330 & -0.0871 & 0.1300 & -0.1827 & -0.0162 & 0.3411 & 0.3387 & 0.1795 & 0.730 & 0.533 \\
SF & 0.0232 & 0.0215 & -0.0102 & -0.0012 & 0.0038 & 0.0151 & 0.0000 & -0.0252 & -0.048 & -0.066 \\
GYPP & $-0.1945^{*}$ & -0.1639 & $0.3421^{* * *}$ & $0.3923^{* * *}$ & 0.0881 & -0.0673 & -0.0606 & $0.2432^{* * *}$ & $0.539^{* * *}$ & $0.663^{* * *}$ \\
Partial R & -0.0036 & 0.0160 & 0.0375 & 0.2549 & -0.0042 & 0.0011 & 0.0115 & 0.0868 & 0.3941 & -0.0439 \\
\hline
\end{tabular}

$\mathrm{R}^{2}$ : 0.7502; residual effect: $0.4998 ; *$ : Significant at $p<0.05 ; * *$ : Significant at $p<0.01 ; * * *$ Significant at $p<0.001$

\section{Conclusion}

The genotypes exhibited a wide range of variability for most of the traits. This indicated that there is ample scope for selection of promising genotypes for yield improvement. On the basis of per se performance, the genotypes CRR599-4-1 and IR 83142-60 were found to be the best for yield and yield contributing traits. Therefore, these genotypes can be successfully utilized as parents in hybridization programme for evolving rice variety. 


\section{References}

Akhter, K., Iftekharuddaula, K.M., Bashar, M.K., Kabir, M.H., Sarkar, M.Z.A., 2004. Genetic variability, correlation and path analysis in irrigated hybrid rice. Journal of Subtropical Agriculture Research and Development 2, 17-23.

Allard, R.W., 1960. Selection under self-fertilization. Principles of Plant Breeding, John Wiley \& Sons, Inc, 55.

Anis, G., Sabagh, A.E.L., Ghareb, A., Rewainy, I.E.L., 2016. Evaluation of promising lines in rice (Oryza sativa L.) to agronomic and genetic performance under Egyptian conditions. International Journalof Agronomy and Agricultural Research 8(3), 52-57.

Burton, G.W., Devane, E.H., 1953. Estimating heritability in tall fescue (Festuca arundinaceae) from replicated clonal material. Agronomy Journal 45, 478-481.

Chouhan, S.K., Singh, A.K., Singh, A., Singh, N.K., Yadav, S.K., Singh, P.K., 2014. Genetic variability and association analysis in wild rice (Oryza nivara and Oryza rufipogon). Annals of Plant and Soil Research 16(3), 219-223.

Dewey, D.R., Lu, K.H., 1959. A correlation and path coefficient analysis of components of crested wheat grass seed production. Agronomy Journal 51, 515-518.

Fisher, R.A., Yates, F., 1963. Statistical table for Biological, Agricultural and Medical research. 6th ed. Oliver Boyd Ltd. Edinburgh, 23-85.

Ganesan, K.N., 2001. Direct and indirect effect of yield components on grain yield of rice hybrids. Journal of Ecology and Biology 13, 29-33.

Haradari, C., Hittalmani, S., 2017. Character association and path coefficient analysis for yield component traits in rice (Oryza sativa L.) Under moisture stress condition at vegetative stage. Current trends in biomedical engineering and biosciences 2(5), 555597.

Islam, M.Z., Khalequzzaman, M., Bashar, M.K., Ivy, N.A., Haque, M.M., Mian, M.A.K., 2016. Variability assessment of aromatic and fine rice germplasm in Bangladesh based on quantitative traits. The Scientific World Journal, 14.

Khare, R., Singh, A.K., Eram, S., Singh, P.K., 2015. Genetic variability, association and diversity analysis in upland Rice (Oryza sativa L). SAARC Journal of Agriculture 12(2), 40-51.

Krishna, T., Kavita, A., Pushpalata, T., 2010. Genetic variability, heritability and genetic advance for quantitative traits in rice (Oryza sativa L.) accession. Agricultural and Biological Research 26(1), 13-19.

Larik, A.S., Rajput, L.S., 2000. Estimation of selection indices in Brassica juncea L. and Brassica napus L. Pakistan Journal of Botany 32(2), 323-330.

Mustafa, M.A., Elshaikh, M.A.Y., 2007. Variability, correlation and path coefficient analysis for yield and its components in rice. African Crop Science Journal 15(4), 183-189.

Namrata, Sharma, H., Ranwah, B.R., Bisen, P., 2016. Variability Assessment and Path Coefficient Analysis in Groundnut
(Arachis hypogaea L.) Genotypes in Sub- Humid Southern Plains of Rajasthan. Trends in Biosciences 9, 642-646.

Nayak, R., Singh, V.K., Singh, A., Singh, P.K., 2016. Genetic variability, character association and path analysis of rice genotypes. Annals of Plant and Soil Research 18(2), 161-164.

Pankaj, G., Pandey, D.P., Dhirendra, S., 2010. Correlation and path analysis for yield and it's components in rice (Oryza sativa L.). Crop Improvement 37(1), 46-51.

Panwar, A., Dhaka, R.P.S., Vinod, K., 2007. Path analysis of grain yield in rice (Oryza sativa L.). Advances in Plant Science 20, 27-28.

Patra, B.C., Pradhan, K.C., Nayak, S.K., Paynaik, S.S.C., 2006. Genetic variability in lowland rice genotypes. Environment and Ecology 24, 27-31.

Rashmi, D., Saha, S., Loitongbam, B., Singh, S., Singh, P.K., 2017. Genetic variability study for yield and yield components in rice (Oryza sativa L.). International Journal of Agriculture, Environment and Biotechnology 10(2), 171-176.

SAS Institute, 1998. SAS/STAT users guide: Version 9.1, 6.4 ${ }^{\text {th }}$ Ed., Vol. 2. SAS Institute, Cary, North Carolina, USA.

Satyanarayana, P.V., Srinivas, T., Reddy, P.R., Madhavilatha, L., Suneetha, Y., 2005. Studies on variability, correlation and path coefficient analysis for restorer lines in rice (Oryza sativa L.). Research on Crops 6(1), 80-84.

Sawarkar A., Senapati B.K., 2014. Polygenic variations and cause effect relationship in some photo-insensitive recombinant inbred lines (RILs) of basmati derivative. African Journal of Biotechnology 13, 112-118.

Searle, S.R., 1961. Phenotypic, genetic and environmental correlation. Biometrics 17, 474-480.

Shah, S., Rashmi, D., Loitongbam, B., Bisen, P., Singh, V.K., Singh, U.S., Singh, P.K., 2017. Genetic analysis of F4: F5 marker assisted derived lines of rice against bacterial leaf blight (BLB) and their marker validation. VegetosAn International Journal of Plant Research 30(special), 101-108.

Shobha Rani, N., Rama Prasad, A.S., Prasad, G.S.V., Bhaskara Reddy, P., Krishna Veni, B., 2001. Genetic variability for yield component in aromatic and quality rice germplasm. Indian Journal of Plant Genetic Resources 14, 206-209.

Singh, A., Saini, R., Singh, J., Arya, M., Mukh Ram, Pallavi, Mukul, Singh, P.K., 2015. Genetic diversity studies in rice (Oryza sativa L.) using microsatellite markers. International Journal of Agriculture Environment and Biotechnology 8, 143-152.

Singh, A., Singh, A.K., Praveen, S., Singh, P.K., 2013. Studies on genetic characteristic of upland rice (Oryza Sativa L.). International Journal of Agriculture Environment and Biotechnology 6(4), 515-520.

Singh, A.K., Nandan, R., Singh, P.K., 2014. Genetic variability and association analysis in rice germplasm under rainfed conditions. Crops Research 47(1-3), 7-11. 
Singh, A.K., Singh, R.K., Kumar, S., Arya, M., Singh, P.K., 2015a. Genetic variability to improve yield and resistance to bacterial leaf blight in rice. Bangladesh Journal of Botany 44(4), 581-589.

Singh, P.K., Dhakad, B.K., Singh, H.B., Singh, A.K., 2012. Genetic variability and association analysis in rice (Oryza sativa L.) treated with Trichoderma harzianum. Crop Research 44, 141-145.

Solanki, G., Dodiya, N.S., Kunwar, R., Bisen, P., Kumar, R., Singh, J., Sandhya., 2017. Character Association and Path Coefficient Analysis for Seed Yield and Latex Yield in Opium Poppy (Papaver somniferum L.). International Journal of Current Microbiology and Applied Sciences 6(8), 1116-1123.

Souroush, H.R., Mesbah, M., Hossainzadeh, A., Bozorgipour, R., 2004. Genetic and phenotypic variability and cluster analysis for quantitative and qualitative traits of rice. Seed and Plant 20(2), 167-182.

Subudhi, H.N., Das, S., Swain, D., Singh, O.N., 2011. Variability, correlation and path analysis for quality characters in rice. Oryza, 48(4), 319-323.
Tripathi, A., Kumar, S., Singh, M.K., Kumar, A., Karnwal, M.K., 2017. Phenotypic assessment of rice (Oryza sativa L.) genotypes for genetic variability and varietal diversity under direct seeded condition. Journal of Applied and Natural Science 9(1), 6-9.

Tuhina-Khatun, M., Hanafi, M.M., Rafii Yusop, M., Wong, M.Y., Salleh, F.M., Ferdous, J., 2015. Genetic variation, heritability, and diversity analysis of upland rice (Oryza sativa $\mathrm{L}$.) genotypes based on quantitative traits. BioMed research international, 7 .

Wright, S., 1934. Correlation and causation. Journal of Agricultural Research 20(7), 557-585.

Yadav, P.N., Chauhan, M.P., Singh, R.S., 2002. Genetic variability, heritability and expected genetic advance for certain quantitative characters in rice. New Agricultural 13(112), 89-94. 